\title{
Zac1 plays a key role in the development of specific neuronal subsets in the mouse cerebellum
}

\author{
Seung-Hyuk Chung ${ }^{1 *}$, Hassan Marzban ${ }^{1}$, Kimberly Aldinger ${ }^{2}$, Rajiv Dixit ${ }^{3}$, Kathleen Millen ${ }^{2}$, Carol Schuurmans ${ }^{3}$ and \\ Richard Hawkes ${ }^{1 *}$
}

\begin{abstract}
Background: The cerebellum is composed of a diverse array of neuronal subtypes. Here we have used a candidate approach to identify Zac1, a tumor suppressor gene encoding a zinc finger transcription factor, as a new player in the transcriptional network required for the development of a specific subset of cerebellar nuclei and a population of Golgi cells in the cerebellar cortex.
\end{abstract}

Results: We found that Zac1 has a complex expression profile in the developing cerebellum, including in two proliferating progenitor populations; the cerebellar ventricular zone and the external granular layer overlying posterior cerebellar lobules IX and X. Zac1 is also expressed in some postmitotic cerebellar neurons, including a subset of GABAergic interneurons in the medial cerebellar nuclei. Notably, GABAergic interneurons in the cerebellar nuclei are derived from the cerebellar ventricular zone, where Zac1 is also expressed, consistent with a lineage relationship between these two $\mathrm{Zac}^{+}$populations. Zac1 is also expressed in a small subset of cells in the posterior vermis, including some neurogranin-immunoreactive $\left(\mathrm{NG}^{+}\right)$Golgi cells, which, based on short-term birthdating, are derived from the EGL, where Zac1 is also expressed. However, Zac1 ${ }^{+}$cells and $\mathrm{NG}^{+}$Golgi cells in the cerebellar cortex also display unique properties, as they are generated within different, albeit overlapping, time windows. Finally, consistent with the expression profile of Zac1, two conspicuous abnormalities were found in the cerebellum of Zac1 null mice: the medial cerebellar nuclei, and not the others, were significantly reduced in size; and the number of Golgi cells in cerebellar lobule IX was reduced by approximately 60\% compared to wild-type littermates.

Conclusions: The data presented here indicate that the tumor suppressor gene Zac1 is expressed in a complex fashion in the developing cerebellum, including in two dividing progenitor populations and in specific subsets of postmitotic neurons, including Golgi cells and GABAergic neurons in the medial nuclei, which require Zac1 for their differentiation. We thus conclude that Zac1 is a critical regulator of normal cerebellar development, adding a new transcriptional regulator to the growing list of factors involved in generating neuronal diversity in the developing cerebellum.

\section{Background}

The cerebellum has two major cellular divisions - the cerebellar cortex and the cerebellar nuclei. The cerebellar cortex is subdivided into distinct laminae, each with characteristic cellular compositions, and the cortical sheet is highly parcellated into a stereotyped array of transverse zones and parasagittal stripes \{for example, [1]). The efferent output of the cerebellar cortex terminates on the cerebellar and vestibular nuclei, which also

\footnotetext{
* Correspondence: sehchung@ucdavis.edu; rhawkes@ucalgary.ca 'Department of Cell Biology and Anatomy, Hotchkiss Brain Institute, and Genes and Development Research Group, Faculty of Medicine, University of Calgary, Calgary, Alberta T2N 4N1, Canada

Full list of author information is available at the end of the article
}

possess a complex cytoarchitecture [2]. Two progenitor cell zones are thought to give rise to all cerebellar neurons: the cerebellar ventricular zone (VZ) and the rhombic lip.

Transcriptional regulators control neuronal fate specification and differentiation events throughout the developing central and peripheral nervous systems. Notably, several basic-helix-loop-helix factors, including Ptf1a and Atoh1/Math1 in the cerebellum [3] and Neurog2 and Ascl1/Mash1 in the telencephalon [4,5], function in opposition to control binary fate choices between glutamatergic and GABAergic neurotransmitter identities. However, in the cerebellum, neuronal classification based solely on neurotransmitter phenotypes does not

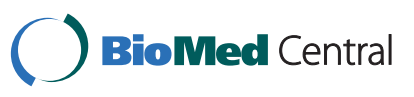

(c) 2011 Chung et al; licensee BioMed Central Ltd. This is an Open Access article distributed under the terms of the Creative Commons Attribution License (http://creativecommons.org/licenses/by/2.0), which permits unrestricted use, distribution, and reproduction in any medium, provided the original work is properly cited. 
accurately portray the wide diversity of neuronal subtypes. Consequently, factors other than Ptf1a and Atoh1 must contribute to the specification and differentiation of distinct cerebellar neurons. We focused our analyses on Zac1 (zinc finger protein that regulates apoptosis and cell-cycle arrest; also known as Lot1 (lost on transformation) and Plagl1 (pleiomorphic adenoma gene like 1)), which encodes a seven $\mathrm{C} 2 \mathrm{H} 2$ zinc finger domain protein that can act as an activator, repressor, co-activator or co-repressor of transcription [6-10]. Zac1 is a maternally imprinted gene, as are several genes involved in growth control and for which gene dosage is critical $[11,12]$. Accordingly, both the overexpression of Zac1 in humans (due to loss of imprinting) and a null mutation in mouse result in intrauterine growth restriction [13-15]. Zac1 is also a tumor suppressor gene, promoting cell cycle arrest and apoptosis in cell lines, while germline mutations are associated with numerous carcinomas in humans [16-20]. During mouse embryonic and early postnatal development, Zac1 is highly expressed in numerous neuroepithelia with active proliferation, including the neuroepithelium of the fourth ventricle and the external granular layer (EGL) of the cerebellum $[21,22]$. Recently, Zac1 was shown to elicit apoptosis and cell cycle arrest in the developing murine retina [23] and to influence retinal cell fate decisions in both mouse [23] and Xenopus [24]. Specifically, in Zac1 null mutant mice, the retina becomes hypercellular in late retinogenesis with a specific expansion of amacrine cell and rod photoreceptor populations [23].

Here we show that Zac1 is expressed in a restricted manner in the developing cerebellum, suggestive of a role in the formation of two specific subsets of GABAergic neurons - a specific sub-group of the medial cerebellar nuclei, and a subset of Golgi cells. These hypotheses were confirmed by analysis of the cerebellum of $\mathrm{Zac1}$ null mice: specific defects were identified in both the medial nuclei and Golgi cells of the posterior vermis.

\section{Materials and methods}

\section{Animal maintenance and tissue processing}

All animal procedures conformed to institutional regulations and the Guide of the Care and Use of Experimental Animals from the Canadian Council of Animal Care. CD1 and C57BL/6 mice were obtained from Charles River Laboratories (St Constant, PQ, Canada) and maintained in the Animal Resource Centre at the University of Calgary. The Zac1 mutant allele [15] was maintained on a C57BL/ 6 background and genotyping was performed as described [23]. $\mathrm{Zacl}^{+\mathrm{m} /-}$ heterozygous embryos were effectively $Z a c 1$ null mutants due to maternal imprinting of the Zac1 locus [25], and were generated by crossing $\mathrm{Zac1}^{+/-}$heterozygous males to C57BL/6 females. Atohl $1^{\text {lacZ }}$ mice [26], a generous gift of Dr $\mathrm{H}$ Zoghbi, were maintained as heterozygous breeding pairs and genotyped as described. Embryos were staged using embryonic day (E) 0.5 as the day of the vaginal plug. For postnatal and adult analyses, mice were deeply anaesthetized with sodium pentobarbital $(100 \mathrm{mg} / \mathrm{kg}$, intraperitoneally) and transcardially perfused with $0.9 \% \mathrm{NaCl}$ in $0.1 \mathrm{M}$ phosphate buffer ( $\mathrm{pH}$ 7.4) followed by fixation in $4 \%$ paraformaldehyde with $0.02 \%$ glutaraldehyde in $0.1 \mathrm{M}$ phosphate buffer ( $\mathrm{pH}$ 7.4). The brains were then removed, post-fixed in $4 \%$ paraformaldehyde at $4{ }^{\circ} \mathrm{C}$ for 24 hours and stored in Millonig's solution (pH 7.6). Series of $40-\mu \mathrm{m}$ transverse or sagittal sections were cut through the extent of the cerebellum on a cryostat.

\section{Immunohistochemistry}

Immunohistochemistry was carried out on free-floating sections as described previously $[27,28]$. Briefly, tissue sections were washed thoroughly in phosphate-buffered saline (PBS), and blocked with 10\% normal goat serum (Jackson Immunoresearch Laboratories, West Grove, PA, USA). Primary antibodies were diluted in PBS containing $0.1 \%$ Triton-X100 and $5 \%$ bovine serum albumin and sections incubated for 16 to 18 hours at room temperature. For immunoperoxidase labeling, sections were washed thoroughly in PBS and then incubated in biotinylated goat anti-rabbit or biotinylated goat anti-mouse Ig antibody (1:1,000 in blocking solution; Jackson Immunoresearch Laboratories) for 2 hours at room temperature. Antibody binding was revealed with a Vectastain ABC Staining Kit (Vector Laboratories Inc., Burlingame, CA, USA) according to the manufacturer's instructions. Sections were mounted on slides, dehydrated through an alcohol series, cleared in Histoclear, and cover-slipped with Entellan mounting medium (BDH Chemicals, Toronto, ON, Canada). For fluorescent immunolabeling, CY3-conjugated goat anti-rabbit secondary antibody (Alexa conjugated antibodies) and CY2-conjugated goat anti-mouse secondary antibodies were used as above (1:1,000; Jackson Immunoresearch Laboratories). After 2 hours the sections were washed in PBS, mounted onto chrome-alum and gelatin subbed slides, air-dried overnight, cleared, and cover-slipped with non-fluorescing mounting medium (Fluorsave Reagent, Calbiochem, La Jolla, CA, USA).

The following primary antibodies were used: rabbit antiZac1 (1:500) [7]; rabbit anti-neurogranin (anti-NG; 1:1,000; Chemicon, Temecula, CA, USA) [29]; mouse anticalbindin (1:1,000; Swant Inc., Bellinzona, Switzerland); rabbit anti-T-box brain gene 1 (Tbr1; 1:1,000; AbCam Inc., Cambridge, MA, USA) [30]; mouse anti-zebrin II (1:200) [31]; mouse anti-5-bromo-2-deoxyuridine (antiBrdU; 1:500; Developmental Studies Hybridoma Bank, Iowa City, IA, USA); guinea-pig anti-mouse metabotropic glutamate receptor (mGluR)1 $\alpha$ antibody (1:500) [32]; rat 
anti-BrdU (1:500; Cedarlane Laboratories Limited, Hornby, ON, Canada); mouse anti-calretinin (1:1,000; Swant Inc.); rabbit anti-kinesin light chain 3 (anti-KLC3; 1:500) [33].

Photomicrographs were captured with a SPOT Cooled Color digital camera (Diagnostic Instruments Inc (Sterling Heights, MI, USA). running under and assembled in Adobe Photoshop. Confocal images were obtained using an Olympus FV300 confocal microscope. The images were cropped and corrected for brightness and contrast but not otherwise manipulated.

\section{Golgi cell birthdating}

Golgi cells were birthdated by administering intraperitoneal injections of $6 \mathrm{mg}$ BrdU (as a $10 \mathrm{mg} / \mathrm{ml}$ solution in sterile saline) to timed-pregnant dams (E11, E12, E13, E14, E15, E16, and E17). The dams were perfused at postnatal day (P) 5 or P20 and the cerebella from the pups immersion post-fixed and processed for anti-BrdU immunocytochemistry.

\section{Primary cerebellar cultures}

Primary cerebellar cultures were prepared from E18 CD1 mice and maintained 21 days in vitro according to the methods of Furuya et al. [34] and Tabata et al. [35] with some modifications [27]. Briefly, the entire cerebellum was removed and kept in ice-cold $\mathrm{Ca} 2^{+} / \mathrm{Mg}^{+}$-free Hank's balanced salt solution (HBSS) containing gentamicin $(10 \mu \mathrm{g} / \mathrm{ml})$ and glucose $(6 \mathrm{mM})$. The cerebella were incubated at $34^{\circ} \mathrm{C}$ for 12 minutes in HBSS containing $0.1 \%$ trypsin. After washing, the cerebella were gently triturated in HBSS containing DNase I (5 U/ml) and $12 \mathrm{mM} \mathrm{MgSO}_{4}$ until the cell mass was no longer visible. The cells were collected by centrifugation and resuspended in seeding medium (1:1 Dulbecco's modified Eagle's medium and F-12) supplemented with putrescine (100 $\mu \mathrm{M})$, sodium selenite $(30 \mathrm{nM})$, L-glutamine $(1.4 \mathrm{mM})$, gentamicin $(5 \mu \mathrm{g} / \mathrm{ml})$, and $10 \%$ heat-inactivated fetal bovine serum. The cell suspensions were seeded on poly-L-ornithine coated glass coverslips $(12 \mathrm{~mm})$ at a density of $5 \times 10^{6}$ cells $/ \mathrm{ml}$, with each coverslip in a well of a $6 \times 4$ well dish. After 6 to 8 hours incubation in a $\mathrm{CO}_{2}$ incubator $\left(100 \%\right.$ humidity, $37^{\circ} \mathrm{C}, 5 \%$ $\mathrm{CO}_{2}$ ), $500 \mu \mathrm{l}$ of culture medium further supplemented with transferrin $(200 \mu \mathrm{g} / \mathrm{ml})$, insulin $(20 \mu \mathrm{g} / \mathrm{ml})$, progesterone $(40 \mathrm{nM})$, and tri-iodothyronine $(0.5 \mathrm{ng} / \mathrm{ml})$ was added to each culture well. Every 7 days, half of the medium in each dish was replaced with fresh culture medium additionally supplemented with cytosine arabinoside $(4 \mu \mathrm{M})$ and bovine serum albumin $(100 \mu \mathrm{g} / \mathrm{ml})$.

\section{Cell counts}

To estimate the number of Golgi cells in wild-type and null cerebellar cortices, NG-immunoreactive Golgi cells were counted from transverse sections through the full width of the vermis of cerebellar lobules V, VI and IX $(+/+, \mathrm{N}=4 ;+\mathrm{m} /-, \mathrm{N}=3)$.

\section{Results}

Zac1 and Tbr1 distinguish GABAergic and glutamatergic subdivisions of the medial cerebellar nuclei

Previous studies have used RNA in situ hybridization to characterize the distribution of $Z a c 1$ transcripts in the developing cerebellum, revealing a restricted cellular pattern suggestive of a role for this factor in the specification and/or differentiation of specific cerebellar cell populations [22]. To better understand how Zac1 might function during cerebellar development, we performed a detailed spatiotemporal expression analysis using Zac1specific antisera [7]. We first examined whether Zac1 protein was detected in either of the cerebellar progenitor cell zones - the rhombic lip or the cerebellar VZ from which all cerebellar neurons are derived. To provide a frame of reference, we compared the expression of Zac1 to Tbr1, a T-box transcription factor that is expressed in a subset of rhombic-lip derived, glutamatergic neurons.

At E11, Zac1 immunoreactivity was detected in the cerebellar VZ overlying the fourth ventricle and not in the rhombic lip (Figure 1A). In contrast, Tbr1, which labels a subset of postmitotic cells derived from the rhombic lip, was not expressed at E11 (Figure 1B). By $\mathrm{E} 12, \mathrm{Zac}^{+}$cells were detected in the VZ and in a continuous stream of cells that appeared to be migrating dorsally from the $\mathrm{VZ}$ towards the cortical transitory zone (Figure 1C). Conversely, at E12, Tbr1 labeled a subpial stream of cells at the dorsal surface of the cerebellar anlage, a cell population that is derived from rhombic lip progenitors [36]. At E13, $\mathrm{Zac1}^{+}$cells were evident in the $\mathrm{VZ}$ and in the cortical transitory zone, labeling a discrete cluster in the center of the cerebellar anlage (Figure 1E). The $\mathrm{Zac}^{+}$cell clusters were immediately adjacent to more dorsal clusters of $\mathrm{Tbr}^{+}$cells that had formed in the nuclear transitory zone after migrating through the subpial stream (Figure 1F) [36]. By $\mathrm{P} 0, \mathrm{Zac}^{+}$cells formed symmetrical cell aggregations located ventral to the medial cerebellar nuclei (Figure $1 \mathrm{G}, \mathrm{I})$ and rostral to the $\mathrm{Tbr} 1^{+}$subdivision of the medial nuclei (Figure $1 \mathrm{H}$ ).

Zac1 and Tbr1 are thus expressed in distinct subdivisions of the medial cerebellar nuclei. Such a segregation could be explained if Zac1 was expressed in GABAergic cells derived from the cerebellar VZ, as suggested by its expression pattern, whereas Tbr1 labeled glutamatergic cells derived from the rhombic lip. Indeed, doubleimmunofluorescence labeling of transverse sections confirmed that $\mathrm{Zac1}^{+}$cells in the cerebellar nuclei are GABAergic (P3; Figure $1 \mathrm{~K}-\mathrm{M})$ whereas $\mathrm{Tbr} 1^{+}$cells are 


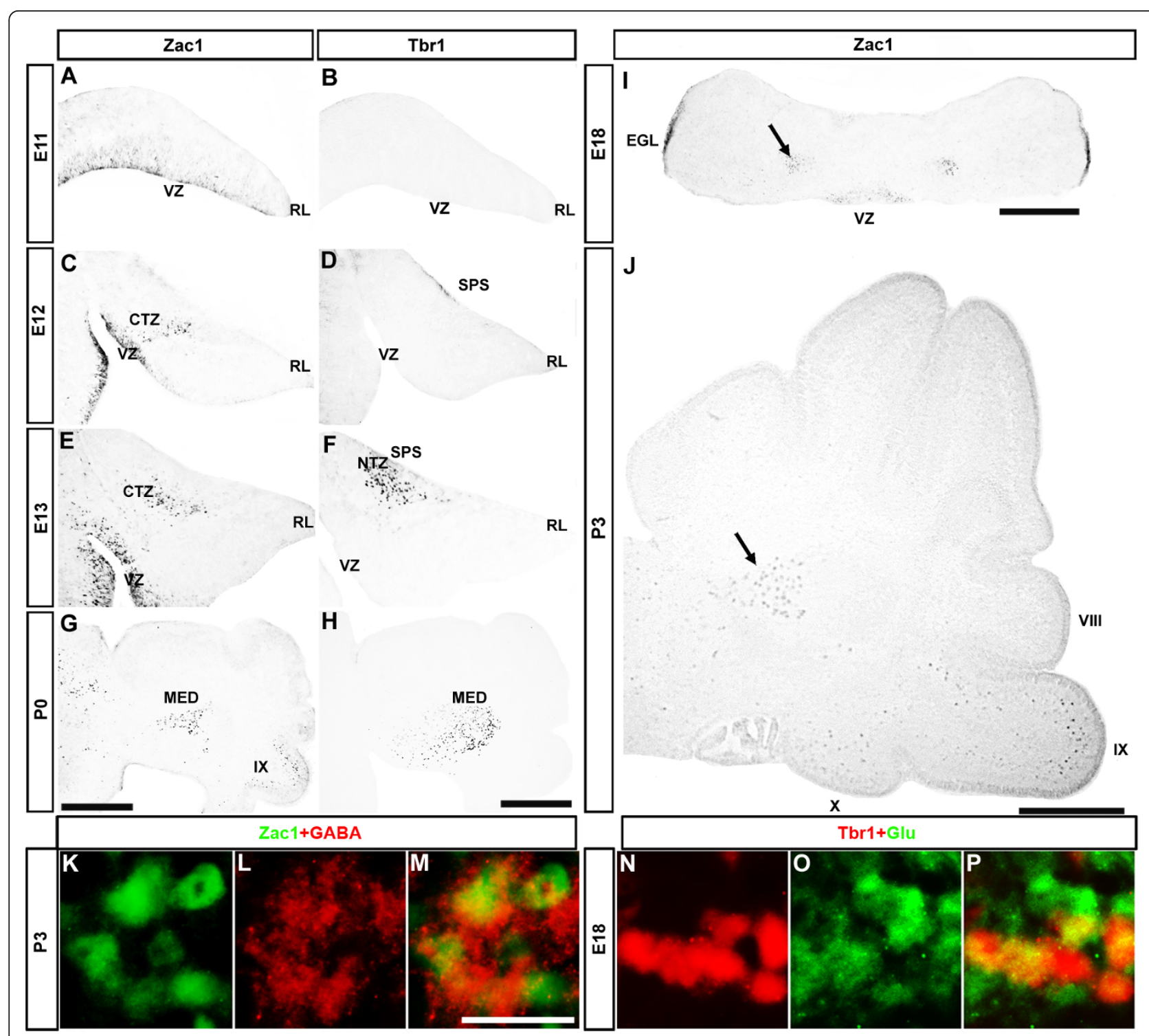

Figure 1 Zac1 and Tbr1 mark distinct cell populations in the developing cerebellum. (A-H) Expression of Zac1 (A,C,E,G) and Tbr1 (B,D,F,H) in $\mathrm{E} 11(\mathrm{~A}, \mathrm{~B}), \mathrm{E} 12(\mathrm{C}, \mathrm{D}), \mathrm{E} 13(\mathrm{E}, \mathrm{F})$ and $\mathrm{P0}(\mathrm{G}, \mathrm{H})$ neighboring sagittal sections of the cerebellum. (I,J) Expression of Zac1 in E18 transverse sections (I) and P3 sagittal sections (J) of the cerebellum. Arrows in (I,J) mark the medial nucleus. (K-M) Transverse section of P3 cerebellum labeled with anti-Zac1 (green) and anti-GABA (red). (N-P) Transverse section of E18 cerebellum labeled with anti-Tbr1 (red) and anti-glutamate (green). Scale bars: $500 \mu \mathrm{m}(\mathrm{H}, \mathrm{I}) ; 250 \mu \mathrm{m}(\mathrm{J}) ; 25 \mu \mathrm{m}(\mathrm{M})$. CTZ, cortical transitory zone; MED, medial nucleus; NTZ, nuclear transitory zone; RL, rhombic lip; SPS, subpial stream; VZ, ventricular zone.

glutamatergic (E18.5; Figure 1N-P) [36]. We have thus identified Zac1 as a novel marker of GABAergic neurons in the medial nuclei of the cerebellum.

\section{Zac1 is expressed in the external granular layer and its derivatives}

In cerebellar sections at E18 (Figure 1I), P0 (Figure 1G) and P3 (Figure 1J), we noted that Zac1 was expressed in several cell populations in addition to the medial nuclei. Firstly, at E18, Zac1 continued to be expressed in VZ progenitors, which are thought to give rise to late-born populations of GABAergic neurons in the cerebellar nuclei and cortex [37]. Zac1 immunoreactivity in the cerebellar VZ disappeared by around P3. Secondly, Zac1 expression was evident in the EGL of the posterior cerebellum beginning at E16 (presumptive lobules IX and X; Figure 2A). At this stage, no $\mathrm{Zac1}^{+}$cells were detected in the internal granular layer. By E18, $\mathrm{Zac1}^{+}$cells appeared to migrate inwards from the outer layer of the EGL into the immature molecular layer (Figures 1I and $2 \mathrm{~B}, \mathrm{M}) . \mathrm{Zac}^{+}$cells were also observed in the granular layers of presumptive cerebellar lobules IX and X but 


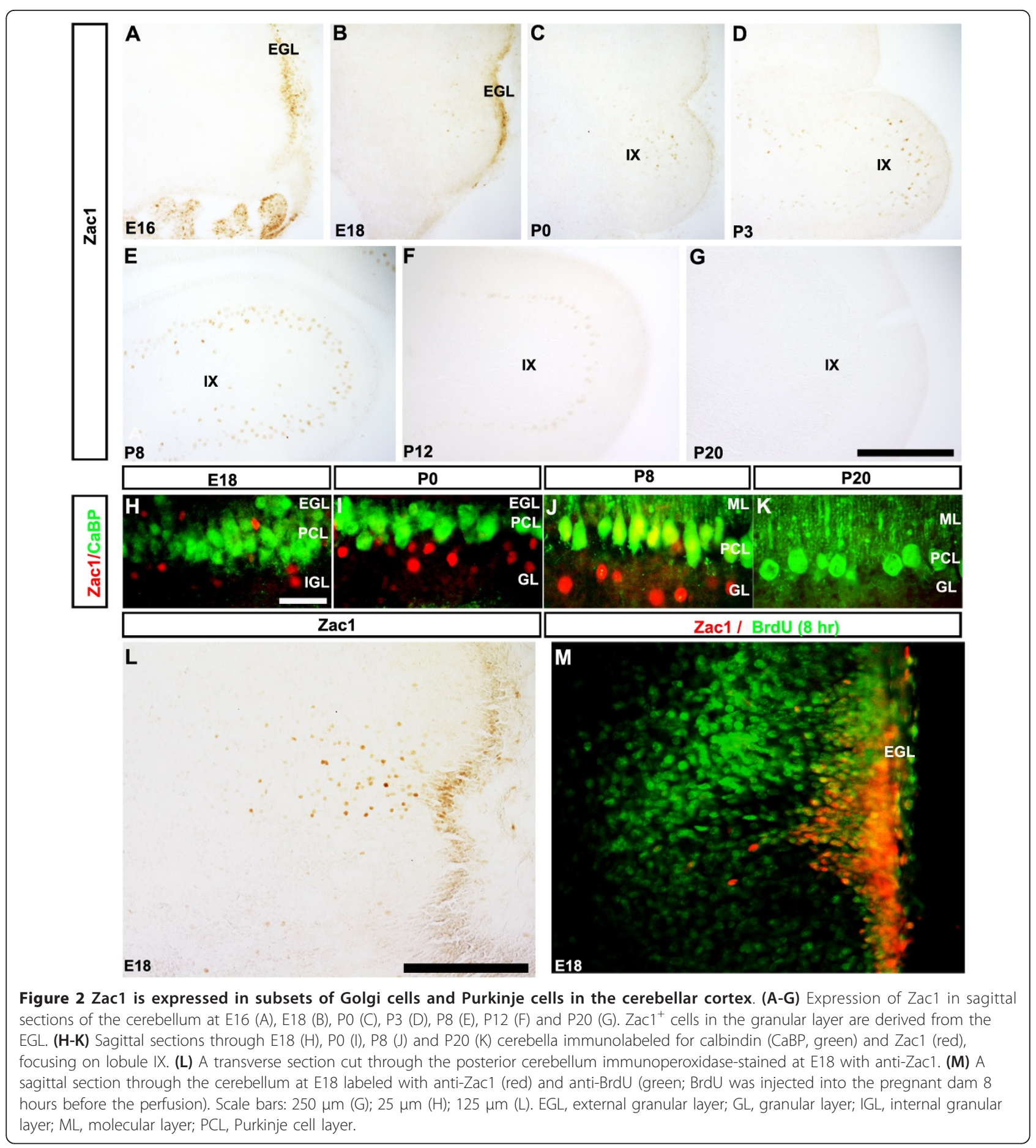

not other lobules at P0 (Figure 2C), P3 (Figures 1J and 2D) and P8 (Figure 2E). Zac1 immunoreactivity in the granular layer started to disappear at around P12 (Figure 2F) and no cells in the granular layer expressing Zac1 were observed by P20 (Figure 2G) or in the adult (data not shown). Indeed, no Zac1 protein was detected in the adult mouse cerebellum (data not shown).
The pattern of anti-Zac1 immunostaining in the EGL of lobules IX/X and in adjacent internal layers suggested that $\mathrm{Zac}^{+}$EGL cells may migrate to form a discrete population of neurons in the granular layer of these lobules. To follow this putative migration process, and to better localize $\mathrm{Zac}^{+}$cells, we performed double immunolabeling with anti-Zac1 and anti-calbindin, a 
specific marker of all Purkinje cells in the adult cerebellum (for example, [38]) and subsets of Purkinje cells perinatally (for example, [29]). At E18, Zac1 and calbindin were expressed in distinct sets of cerebellar cells (Figure $2 \mathrm{H}$ ). $\mathrm{Zac1}^{+}$cells were detected in the EGL, as anticipated, and were also interspersed throughout the calbindin ${ }^{+}$Purkinje cell layer, and in the underlying internal granule layer (Figure 2H). By P0, Zac1 expression was absent from the external granule layer, with most Zac1 immunoreactivity located beneath the Purkinje cell layer in the underlying granule layer (Figure 2I). At P8, Zac1 continued to be expressed in the internal granule layer, and was also detected in a subset of calbindin ${ }^{+}$Purkinje cells (Figure 2J). By P20, Zac1 expression was extinguished in both the internal granule and Purkinje cell layers (Figure $2 \mathrm{~K}$ ).

Taken together, the spatially dynamic expression profile suggested that $\mathrm{Zac}^{+}$cells may migrate inwards to the internal granular layer from the EGL. To address this possibility further, we focused on E18, a dynamic stage during which $\mathrm{Zac}^{+}$cells appeared to be migrating from the overlying EGL (Figure 2L). To label EGL cells and their derivatives, time-staged pregnant females were exposed at E18 to BrdU, a synthetic thymidine analog incorporated into newly synthesized DNA in dividing cells. Embryos were harvested 8 hours later and double-immunolabeled with anti-Zac1 and anti-BrdU (Figure 2M). Many Zac1 ${ }^{+}$cells in the EGL, where proliferating progenitors are located, and in the underlying cellular layers, where differentiated neurons migrate, incorporated $\mathrm{BrdU}$. The $\mathrm{Zac1}^{+} / \mathrm{BrdU}^{+}$labeling pattern was thus consistent with the hypothesis that $\mathrm{Zac1}^{+}$progenitors in the EGL give rise to neurons that take up a final position in the cerebellar cortex. The identity of these putative EGL-derived neurons was further investigated (see below).

\section{Zac1 is expressed in a subpopulation of Purkinje cells}

As noted above, from P8 Zac1 immunoreactivity was detected in a subset of Purkinje cells located in the posterior cerebellum (cerebellar lobules IV to X; Figure 2J). Inspection of the high power images indicated that Zac1 protein was restricted to the nuclei of Purkinje cells, as expected of a transcriptional regulator (Figure 2E,F,J). No $\mathrm{Zac}^{+}$Purkinje cell axons or dendrites were seen. Although not all Purkinje cells express Zac1, there was no clear evidence of parasagittal stripes (such as are revealed by other markers of early postnatal Purkinje cell subsets for example, NG [29], HSP25 [39], and so on; reviewed in [40]). By P13/14, Zac1 expression had extended to include the majority of Purkinje cells in all lobules of the vermis and most of the Purkinje cells in the hemispheres (data not shown). There were also reproducible differences in the levels of Zac1 immunoreactivity between Purkinje cells in the anterior lobules (weaker) and those in the caudal portion of the vermis (stronger). Purkinje cell Zac1 expression was transient and was no longer detected by P20 (Figure 2G).

\section{Zac1 is expressed in a population of late-born Golgi cells}

To identify the $\mathrm{Zac}^{+}$cells in the granular layer of the posterior lobules, a variety of immunocytochemical markers were employed to distinguish between specific populations of cerebellar neurons. The calcium binding protein calretinin and metabotropic glutamate receptor (mGluR) $1 \alpha$ is a marker for a subset of unipolar brush cells in the cerebellum [41-43], while parvalbumin, also a calcium-binding protein, is expressed by basket and stellate cells (inter alia) [44]. NG is a calmodulin-binding protein found in Golgi interneurons in the adult cerebellum [45]. In the adult mouse, cerebellar cortex NG immunoreactivity is restricted to the somata and dendritic arbors of a subset of Golgi cells $[45,46]$. In addition, weak expression is seen during postnatal development in a small subset of Purkinje cells, restricted primarily to the nodular zone, which is easily distinguished from the Golgi cells [29].

In P7 cerebella, calretinin ${ }^{+}$(Figure $3 \mathrm{~A}-\mathrm{C}$ ), mGluR $1 \alpha^{+}$ (Figure 3D-F), and parvalbumin ${ }^{+}$cells (Figure 3G-I) were not co-labeled with $\mathrm{Zac}^{+}$cells, suggesting that Zac1 is not expressed in subsets of unipolar brush, basket or stellate cells. In contrast, Zac1 and NG were co-expressed in a subset of cells in P7 cerebella (Figure 3J) and in E18 cerebellar cells dissociated and cultured for 21 days in vitro (Figure $3 \mathrm{~K}, \mathrm{~L}$ ), indicating that Zac1 is expressed in some $\mathrm{NG}^{+}$Golgi cells both in vivo and in vitro. Notably, the $\mathrm{Zac}^{+}$cells that did not co-express NG may include: Golgi cells that have not yet initiated NG expression (or in which NG expression has been extinguished); a subpopulation of NG-negative Golgi cells, which have been previously described [46]; and/or other cerebellar cell types (for example, granule cells). While lineage tracing and additional marker analyses would be required to make these distinctions, we can conclude from our studies that Zac1 is expressed in a subset of $\mathrm{NG}^{+}$Golgi cells.

While the origin and birthdate of Golgi cells has been controversial, Zac1 is expressed in both of the putative progenitor zones, including the EGL [47-49] and the VZ of the fourth ventricle [47-49]. Based on previous studies [50-52], and our demonstration that $\mathrm{Zac}^{+}$progenitors from the EGL migrate into the internal granular layer, where some cells continue to express Zac1 and differentiate into $\mathrm{NG}^{+}$Golgi cells, it may be that while most Golgi cells are derived from the neuronal epithelium of the fourth ventricle, a subset of $\mathrm{Zac}^{+}$Golgi cells may also originate in the EGL. To better understand the origin and identity of $\mathrm{Zac}^{+}$cells in the cerebellar cortex, we analyzed their birthdates, comparing them to the birthdates of $\mathrm{NG}^{+}$Golgi cells. 


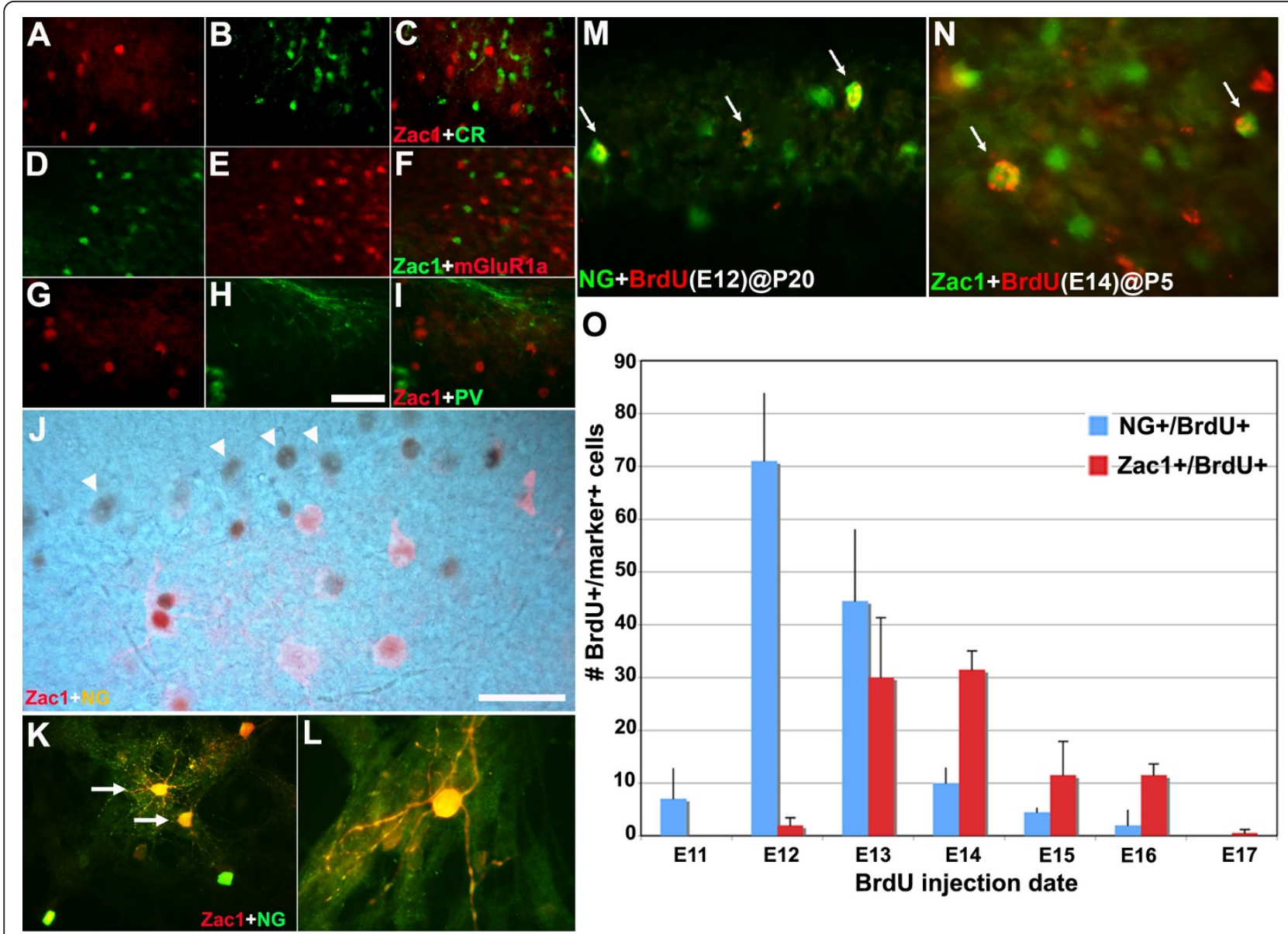

Figure 3 Zac1 marks a subset of late-born cerebellar Golgi cells. (A-J) Double immunofluorescence staining of P7 cerebella for Zac1 and calretinin (A-C), mGluR1 $\alpha$ (D-F), parvalbumin (G-I) and NG (J; first immunoperoxidase stained with DAB for Zac1 (brown), then fluorescence stained for NG (red)). Arrowheads in (J) mark Purkinje cells. (K,L) Primary cultures of E18 mouse cerebella (21 days in vitro) co-labeled with antiZac1 (red) and anti-NG (green). Arrows in (K) mark Zac1 ${ }^{+}$Golgi cells that co-express NG. (M,N) Birthdating of NG ${ }^{+}(\mathbf{M})$ and Zac1 ${ }^{+}$(N) Golgi cells, showing cells labeled with BrdU injections at E12 and analyzed at P20 (M) and BrdU injections at E14 and analyzed at P5 (N). (O) Quantification of the distribution of BrdU-immunostained Golgi cell nuclei in the P5 (for Zac1) and P20 (for NG) cerebellar cortex after exposure to BrdU at different stages during embryonic development (each stage, $\mathrm{N}=4$ pups, counted from sagittal sections; error bars represent standard deviation). Scale bars: $25 \mu \mathrm{m}(\mathrm{H}, \mathrm{J})$.

To analyze neuronal birthdates, the cerebellar cortex was sectioned at P5 (for Zac1 expression) or P20 (for NG expression) after a single exposure to BrdU at times between E11 and E17 (most Golgi cells are born prenatally [51-56]). Cells that were co-labeled with $\mathrm{Zac1} / \mathrm{BrdU}$ and NG/BrdU were quantified in the posterior cerebellar lobules. The earliest $\mathrm{Zac}^{+}$cells were born at E12, the numbers peaking at E13 to E14 and declining by E15 to E17 (Figure 3H). Based on the morphology and location of the $\mathrm{Zac1}^{+} / \mathrm{BrdU}^{+}$cells, and our demonstration that Zac1 is co-expressed with NG, we concluded that a subset of the birthdated $\mathrm{Zac}^{+}$cells were Golgi cells. Consistent with this interpretation, there was some overlap in the period of $\mathrm{NG}^{+}$Golgi cell genesis. However, the bulk of the $\mathrm{NG}^{+}$ Golgi cell population was born at E11, one day earlier than the $\mathrm{Zac}^{+}$cells (Figure $3 \mathrm{O}$ ). The $\mathrm{NG}^{+}$population also showed a protracted period of genesis, peaking at E12 and E13, with fewer born between E14 and E16 (Figure 30 ). There are at least two possible interpretations of these data. The model we favor is that there are two distinct waves of cerebellar Golgi cell differentiation: an early wave including the generation of $\mathrm{NG}^{+}$cells that are born in the highest numbers between E12 and E13; and a second wave including the generation of $\mathrm{Zac}^{+}$Golgi cells that reaches its peak between E13 and E14. As a corollary to this model, the Golgi cells that co-express Zac1 and NG may differentiate in an overlapping period. However, we cannot rule out a second possibility, which is that the $\mathrm{Zac}^{+}$cells that are born outside of the window of $\mathrm{NG}^{+}$ cell genesis are not Golgi cells. Nevertheless, with our studies, we have identified the temporal window during which $\mathrm{Zac}^{+}$cells in the cerebellar cortex differentiate, 
and we have demonstrated that there is some overlap with the genesis of $\mathrm{NG}^{+}$Golgi cells, as expected.

\section{Zac1 expression is lost in the Atoh1 mutant EGL and Golgi cells}

To provide further proof that $\mathrm{Zac}^{+}$Golgi cells are indeed derived from the EGL, we investigated Zac1 expression in mice homozygous for a null allele of mouse Atoh1 (atonal homolog 1; Math1). Atoh1 encodes a basic helix-loop-helix transcription factor that is expressed in the rhombic lip and its progeny, including EGL progenitors that differentiate into granule and Golgi cells, and glutamatergic projection neurons in the cerebellar nuclei $[57,58]$. Notably, Atoh1 is required to form the EGL and its derivatives [58], allowing us to determine if $\mathrm{Zac1}^{+}$ cells in the posterior cerebellum, which includes $\mathrm{NG}^{+}$ Golgi cells, are generated in the absence of the EGL. As observed previously, in the wild-type cerebellum at E18.5 (Figures 1I and 2B,L,M), Zac1 is strongly expressed in the posterior EGL and in inwardly migrating cells, some of which are $\mathrm{NG}^{+}$Golgi cells (Figure 4A-C). However, in E18.5 Atoh1 null mutants, Zac1 ${ }^{+}$EGL cells and cells in the underlying cerebellar cortex, which includes Golgi cells, were sharply reduced in number (Figure 4D-F). This is consistent with the hypothesis that $\mathrm{Zac1}^{+}$cells in the cerebellar cortex, including a subset of Golgi cells, derive from the EGL.

We next asked if Zac1 expression was maintained in the medial cerebellar nuclei in Atoh1 mutants. We reasoned that because Atoh1 is not expressed in the cerebellar VZ [57], from which we propose $\mathrm{Zac}^{+}$GABAergic neurons in the medial cerebellar nuclei arise, the maintenance of Zac1 expression in Atoh1 mutants would support our proposed lineage relationship. Notably, the cerebellar VZ gives rise not only to GABAergic neurons in the cerebellar nuclei, but also to other GABAergic populations, including Purkinje cells. Consistent with the lack of Atoh1 expression in this progenitor compartment, no difference was found in the number of Purkinje cells that differentiate in Atoh1 mutants, although a subset of Purkinje cells (approximately 28\%) migrate aberrantly and form ectopias in the absence of Atoh 1 function, revealing a role for the EGL and its derivatives (which do not form in Atoh1 mutants) in guiding Purkinje cell migration [59]. However, we have previously shown that in scrambler mutants, where Purkinje cell migration defects are even more severe, the organization of the deep cerebellar nuclei is intact [33]. We therefore speculated that the cerebellar nuclei would be intact in Atoh1 mutants, and proceeded with our analysis of Zac1 expression. As expected, $\mathrm{Zac}^{+}$cells were detected in the medial nuclei in both wild-type (Figure 4G-I) and Atoh1 mutants (Figure $4 \mathrm{~J}-\mathrm{L}$ ). This is consistent with our interpretation that $\mathrm{Zac}^{+}$cells in the medial cerebellar nuclei are derived from the cerebellar VZ, and do not arise from the rhombic lip or its derivatives.

\section{Defects in the development of the medial cerebellar nuclei in Zac1 mutants}

We found that Zac1 is expressed in a very restricted manner in the developing cerebellum, notably subsets of cerebellar progenitors in the VZ and EGL, and differentiated neurons in the medial nuclei and the posterior cerebellar cortex (Purkinje and Golgi cells). Such a restricted expression pattern suggested that Zac1 might play an essential role in the genesis of these cell types. To examine this possibility, we analyzed the Zac1 null cerebellum [15]. Zac1 is a maternally imprinted gene $[11,12,25]$. We therefore used $\mathrm{Zac1}^{+\mathrm{m} /-}$ heterozygous mice, which had a wild-type maternal allele (that is, inactive due to imprinting), as the equivalent of null mutants. Notably, we previously verified that $Z a c 1^{+\mathrm{m} /-}$ animals are indeed null mutants and do not express Zac1 [23].

We first questioned whether the medial nucleus developed normally in the absence of Zac1 function. Approximately $80 \%$ of $\mathrm{Zac1}^{+\mathrm{m} /-}$ animals die within the first few postnatal days for reasons currently unknown [15]. We therefore first analyzed development of the medial nucleus in E18.5 $\mathrm{Zac1}^{+\mathrm{m} /-}$ embryos, hereafter referred to as Zac1 mutants. In both wild-type and Zac1 mutant embryos, Tbr1+ neurons were detected in the nuclear transitory zone, an expected result given that these neurons are derived from rhombic lip progenitors, which do not express Zac1 (Additional file 1A,B). We also examined the expression of GAD1 (Additional file 1C,D), which labels GABAergic interneurons in the developing deep cerebellar nuclei (DCN), including Zac1 ${ }^{+}$cells (Figure $1 \mathrm{~K}$ ). However, because GAD1 also labels multiple cell populations in the cerebellar cortex, it was not possible to make definitive conclusions as to whether Zac1 was required for the formation of GABAergic neurons in the medial nucleus (Additional file $1 \mathrm{C}, \mathrm{D}$ ).

Although most $Z a c 1^{+\mathrm{m} /-}$ pups die soon after birth, we were able to isolate four adult $Z a c 1^{+\mathrm{m} /-}$ animals for our analyses. To specifically label the cerebellar nuclei, we used the marker KLC3 [33]. In wild-type cerebella, strong and specific KLC3 expression was observed in all major deep cerebellar nuclei, including the lateral, interposed and medial nuclei, and in the vestibular complex (Figure 5A). KLC3 immunostaining suggests that the anterior part of the medial nuclei is missing in Zac1 mutant mice (Figure 5B); this corresponds to the loss of the normal Zac1 expression domain (equivalent to the M6 domain of Chung et al. [2]). The phenotype is restricted to the anterior medial nuclei; the interposed and lateral nuclei appear normal in Zac1 mutants (Figure 5B). 


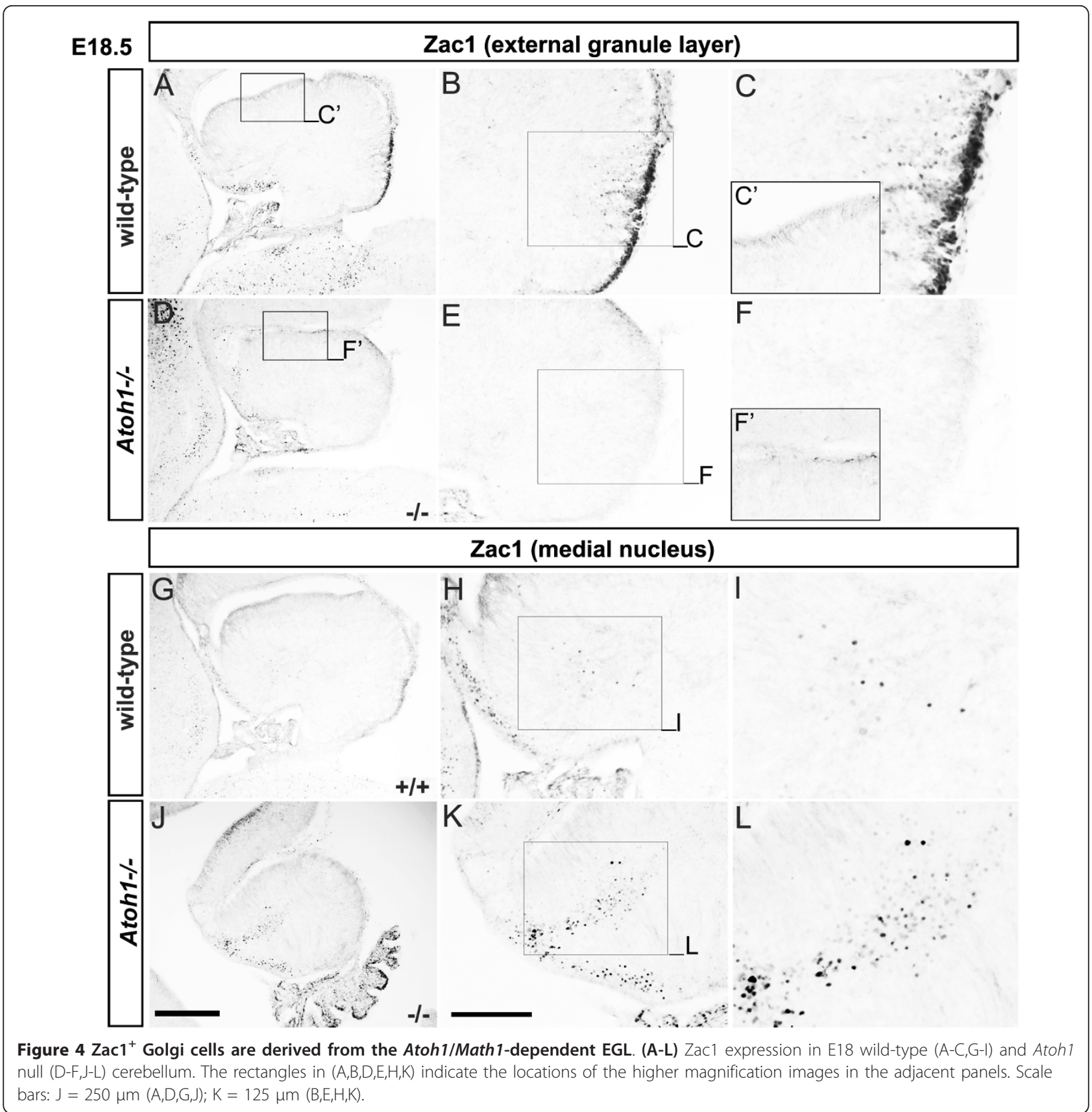

\section{Fewer Golgi cells are generated in Zac1 mutants}

We next investigated whether Zac1 mutants displayed defects in the generation of Purkinje and Golgi cells in the cerebellar cortex. To analyze Purkinje cells in adult Zac1 mutant mice, we first analyzed the expression of calbindin. No abnormalities in calbindin expression were detected in Zac1 mutant cerebella, suggesting that Purkinje cell development occurred normally (data not shown). To address the development of the Purkinje cell layer, we also examined the expression of zebrin II, which labels a subset of Purkinje cells that form parasagittal stripes [31]. In the wild-type cerebellum, three characteristic narrow zebrin II stripes $(\mathrm{P} 1+$ at the midline and $\mathrm{P} 2+$ laterally to either side: for stripe terminology, see [60]) were observed in the anterior zone of lobule II-III (Figure 6A); the characteristic anterior zone zebrin $\mathrm{II}^{+}$stripes appeared normal in the Zac1 null cerebellum (Figure 6B). The same was true of cerebellar patterning in other regions (data not shown).

We next examined whether Golgi cells were generated normally in the absence of Zac1 function by using NG as a cell-type-specific marker. In cerebellar lobule IX of 


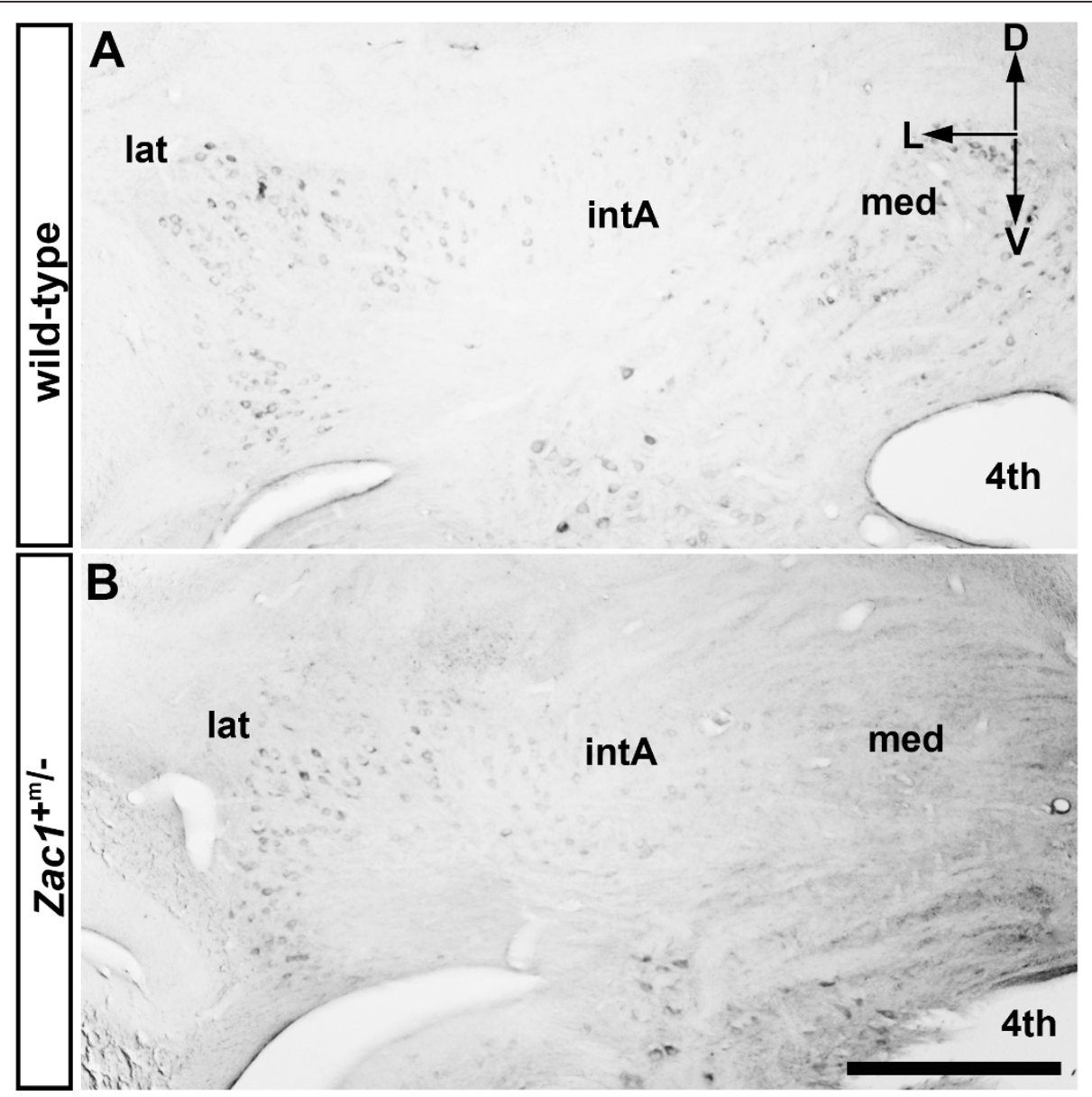

Figure 5 A subdomain of the medial nuclei is missing in Zac1 null mice. (A,B) A transverse section through the cerebellum of KLC3 expression in adult wild-type (A) and Zac1 mutant (B) animals. Strong and specific KLC3 expression is observed in all major cerebellar subnuclei, and in the vestibular complex (A). In the Zac1 null mouse cerebellar cortex, the anterior part of the medial nuclei is absent (B). D, dorsal; $L$, lateral; $V$, ventral; $4^{\text {th }}$, fourth ventricle; med, medial nucleus; intA, anterior interposed nucleus; lat, lateral nucleus. Scale bar: $250 \mu \mathrm{m}$.

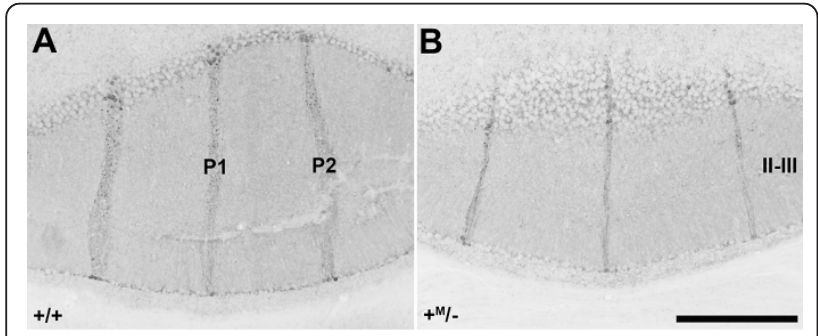

Figure 6 Purkinje cell patterning is not disrupted in Zac1 null mice. (A,B) Expression of zebrin II in the wild-type (A) and Zac1 null (B) adult cerebellum. Three characteristic narrow zebrin II stripes (P1 + at the midline and P2+ laterally to either side: for stripe terminology, see [60]) are observed in the anterior part (lobule II-III) of the wild-type cerebellum (A). The characteristic zebrin IIimmunopositive stripes appear normal in the Zac1 null cerebellum (B). Scale bar: $250 \mu \mathrm{m}$.
Zac1 null mutants (Figure 7B,D), the number of $\mathrm{NG}^{+}$ Golgi cells was significantly reduced in Zac1 mutant mice compared to wild-type littermates (approximately $63 \%$ of wild-type levels: $Z a c 1$ mutant, $427 \pm 11.53 \mathrm{NG}^{+}$ cells; wild type, $674 \pm 10.57 \mathrm{NG}^{+}$cells; $P$-value 0.0005 ; $+/+, \mathrm{N}=4 ;+{ }^{\mathrm{m}} /-, \mathrm{N}=3$; Figure $\left.6 \mathrm{~A}, \mathrm{C}\right)$. As predicted from the normal restriction of Zac1 expression to Golgi cells of the posterior vermis, these losses were restricted to cerebellar lobule IX. In contrast, counts of $\mathrm{NG}^{+}$Golgi cells in lobules $\mathrm{V}$ and VI showed no difference between Zac1 null and wild-type littermates (Zac1 mutant, $376 \pm$ $7.69 \mathrm{NG}^{+}$cells; wild type, $339 \pm 13.05 \mathrm{NG}^{+}$cells; $P$-value: $0.0131 ;+/+, N=4 ;+{ }^{m} /-, N=3$; Figure $\left.7 E, F\right)$. We thus conclude that $Z a c 1$ is required for the generation of a subset of Golgi cells in posterior cerebellar lobule IX. 


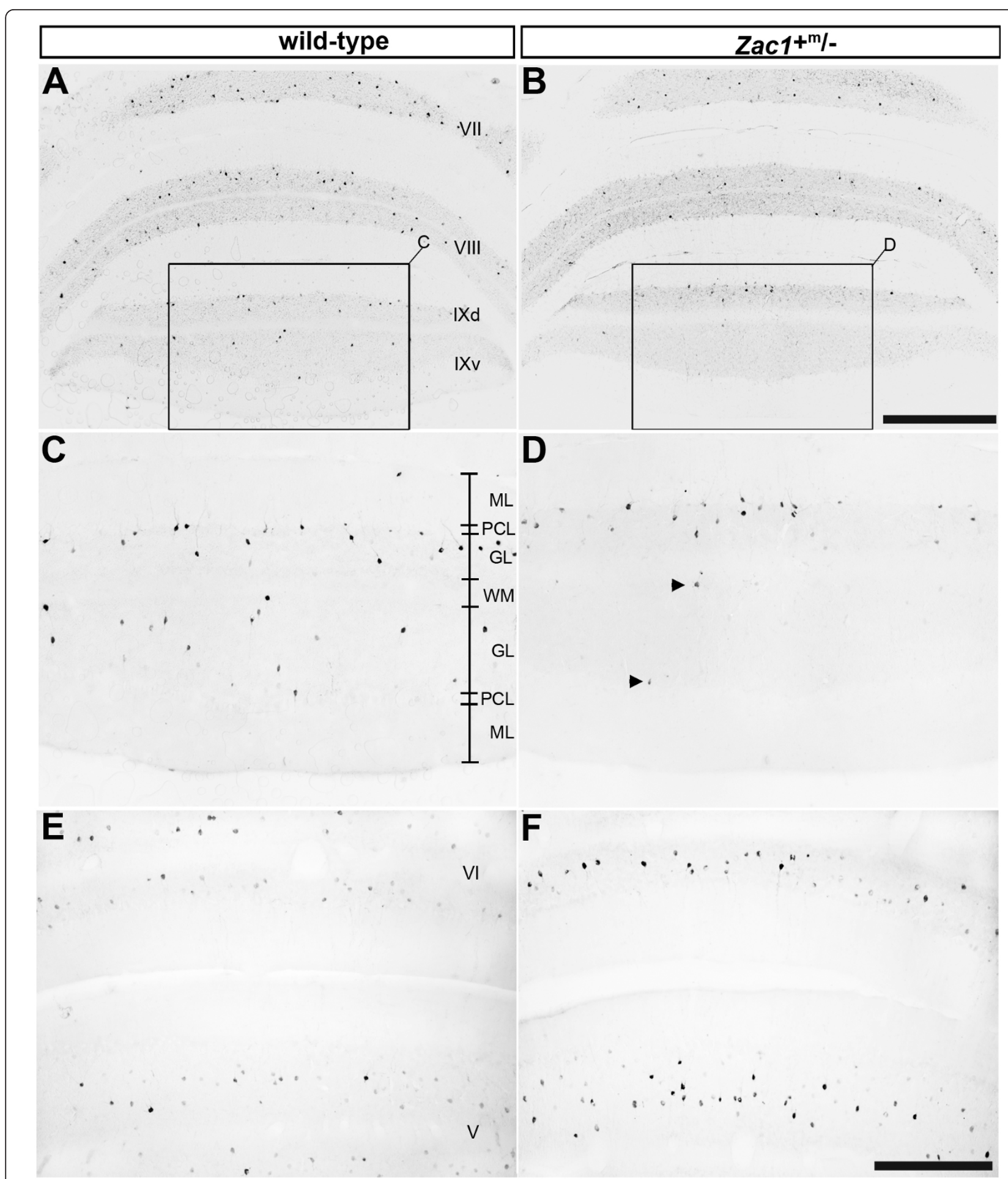

Figure 7 Fewer Golgi cells are detected in Zac1 null mice. (A-F) Expression of NG in transverse sections of wild-type (A,C,E) and Zac1 null (B, $D, F)$ mice, focusing on lobules IX (C,D) and VNI (E,F). Scale bars: $B=250 \mu \mathrm{m}(\mathrm{A}, \mathrm{B}) ; \mathrm{F}=125 \mu \mathrm{m}(\mathrm{C}-\mathrm{F})$. $\mathrm{GL}$, granular layer; $\mathrm{ML}$, $\mathrm{molecular}$ layer; $\mathrm{PCL}$, Purkinje cell layer; WM, white matter tract. 


\section{Discussion}

It is well established that transcription factors are required to specify neural cell identities and initiate subtype-specific neuronal differentiation programs throughout the central and peripheral nervous systems. Yet we are still a long way from having a comprehensive understanding of how neuronal diversity is generated during development, in particular in brain regions with complex morphologies and heterogeneous neuronal populations. The present data reveal a critical role for the transcription factor Zac1 in the generation of two specific cerebellar neuronal populations - one a GABAergic neuronal subset in the medial cerebellar nuclei, the other a subset of Golgi interneurons in the cerebellar cortex.

\section{Zac1 is required in the medial cerebellar nuclei}

Cerebellar nuclear neurons can be broadly subdivided into small GABAergic interneurons and large glutamatergic projection neurons [61-63]. Early studies suggested that both neurochemically distinct subpopulations were derived from the neural epithelium lining the fourth ventricle (that is, the cerebellar VZ) [64-66]. However, recent expression and cell lineage tracing studies have instead indicated that $\mathrm{Tbr}^{+}$glutamatergic projection neurons in the deep cerebellar nuclear neurons originate from Atoh $1^{+}$progenitors in the rhombic lip $[36,57,58]$. A new model has therefore been proposed whereby the rhombic lip is the source for large diameter projection neurons in the cerebellar nuclei, while $\mathrm{Ptfla}^{+}$and $\mathrm{Pax}_{2}^{+}$progenitors in the cerebellar VZ give rise to GABAergic neurons, including small diameter neurons in the cerebellar nuclei $[58,67,68]$. The data presented here are consistent with this hypothesis. We found that Zac1 is also expressed in the cerebellar VZ, where Ptf1a and Pax2 are expressed. Furthermore, we demonstrate that Zac1 is expressed in a small subset of GABAergic interneurons in the medial nucleus, forming clusters that lie just ventral to the Tbr1 ${ }^{+}$, glutamatergic projection neurons. Our data thus support the idea that $\mathrm{Tbr}^{+}{ }^{+}$and $\mathrm{Zac1}^{+}$nuclear neuron subsets are non-overlapping, and that these two populations of neurons have distinct embryological origins. KLC3 is a general marker to assess defects in the medial cerebellar nuclei as it is a specific marker of this region, which includes GABAergic interneurons [33]. The loss of KLC3 expression in the medial cerebellar nuclei in Zac1 null mice further supports a role for Zac1 in the formation of this cell population.

\section{Zac1 is required for the formation of a subset of cerebellar Golgi cells}

Golgi cells [69] are large interneurons with their cell bodies dispersed throughout the granular layer and numerous radiating dendrites [70]. Golgi cell apical dendrites ramify through the molecular layer and are contacted by the axons of granule cells. In addition, a few basolateral dendrites extend in the granular layer (reviewed in [71]). The origin of Golgi cells has been controversial for decades. Originally Popoff [47] and Athias [48] suggested the EGL was the origin of these large neurons. This interpretation was supported by the more recent studies of Hausmann et al. [49], who used cerebellar transplantation to provide experimental evidence that Golgi cells originate from the EGL. However, in contrast, Ramon y Cajal [50] and Altman and Bayer [51] both concluded that Golgi cells are derived from the ventricular neuroepithelium. The same conclusion was reached by Zhang and Goldman [52] based on retroviral lineage tracing data. In fact, the cerebellar VZ is thought to give rise to all cerebellar GABAergic neurons, including Purkinje cells and interneurons such as Golgi, basket and stellate cells in the cerebellar cortex and small diameter interneurons in the cerebellar nuclei $[58,68]$. The data presented here reconcile both hypotheses. We identified a small subset of Zac1-immunopositive Golgi cells that are restricted to the posterior zone, and we provide birthdating evidence to suggest that these Golgi cells are derived from the EGL (presumably the population identified by Haussman et al. [49]). Notably, there is a precedent for the posterior EGL having a distinct molecular signature, as it is only in lobules IX and X that $\mathrm{Lmx} 1 \mathrm{a}^{+}$precursors reside [72]. It is therefore interesting to speculate that the $\mathrm{Zac1}^{+}$Golgi cells could similarly originate from $\mathrm{Lmx} 1 \mathrm{a}^{+}$progenitors in the posterior EGL. In contrast, we suggest that most Zac1-immunonegative Golgi cells instead originate from the neuroepithelium of the fourth ventricle.

Multiple Golgi cell subtypes have been identified based upon expression data but these are not reported to be regionally restricted (for example, $[46,73,74]$ ); unfortunately, there is no temporal overlap of the expression patterns of Zac1 and known subtype markers. The birthdating data show different, but overlapping, birthdate time windows for $\mathrm{NG}^{+}$and $\mathrm{Zac}^{+}$cells. Immunohistochemical analysis with BrdU shows that most $\mathrm{NG}^{+}$Golgi cells are born between E12 and E14 whereas the majority of the $\mathrm{Zac1}^{+}$cells are born between E13 and E16. Thus, we speculate that most NG ${ }^{+}$Golgi cells derive from the neuroepithelium of the fourth ventricle between E12 and E14 (the EGL is not yet formed at this stage), while the smaller $\mathrm{Zac}^{+}$subset of Golgi cells originate from the EGL at a later stage (E13 to E16). However, a Zac1 lineage trace using a Zac1::cre transgene and a reporter line (which presumably would label cells derived from the cerebellar VZ and not the rhombic lip) will be required to provide definitive proof for this interpretation. 
Previous studies have suggested that Zac1 may play an important role in the differentiation of GABAergic progenitor cells. Valente and Auladell [75] showed that $\mathrm{Zac}^{+}$neural progenitor cells in the third and fourth ventricles are GABAergic interneurons that leave the $\mathrm{VZ}$ and migrate to their final destinations. In this study, we have shown that the $\mathrm{Zac}^{+}$medial nuclear neurons are GABAergic and will presumably become a part of the interneurons of the cerebellar nuclei, whereas the $\mathrm{Tbr}^{+}$medial nuclear neurons will form later and become a subset of the cerebellar glutamatergic projection neurons. Golgi cells that express NG are GABAergic, whereas the Golgi cells devoid of NG are either GABAergic/glycinergic or glycinergic only [46]. There is also a small subset of Golgi cells (5 to 10\%) that only express mGluR2 [46]. It is not clear why other GABAergic populations in the cerebellum do not require $\mathrm{Zac1}$ function; from the fourth ventricle, these include Purkinje cells [76] and likely other inhibitory interneurons (for example, [37,77]).

It is not clear how Zac1 might act in the cerebellum. Clearly, the null allele lacks specific classes of neuron subsets of Golgi cells and neurons of the medial nuclei. Zac1 has been best characterized as a tumor suppressor gene ( $\mathrm{Zac1}$ expression in human ovarian carcinoma cell lines was significantly decreased - $36 \%$ of them show an undetectable level of expression [16]). Zac1 expression was also reduced in primary breast cancer [78]. Consistent with this, Kamikihara et al. [79] showed a significant $Z a c 1$ mRNA reduction in primary ovarian cancer. However, other studies show that Zac1 controls normal development as a positive regulator (for example, [80]). Similarly, Ma et al. [23] recently proposed that Zac1 promotes the proliferation of neuronal progenitors in Xenopus retina. Thus, a likely explanation of the cerebellar phenotype is that $\mathrm{Zac1}$ expression is required for the proliferation of the progenitors that give rise to two neuronal subclasses in the cerebellum.

\section{Conclusions}

In this study, we used immunocytochemistry to analyze the Zac1 expression profile during embryonic and postnatal development in the murine cerebellar cortex. The results pointed to a key role for $\mathrm{Zac1}$ in the formation of two specific subsets of GABAergic neurons: one arising from the fourth ventricle and forming a specific subgroup of the medial cerebellar nuclei, and a second derived from the EGL, which forms a specific subset of Golgi cells. This hypothesis was confirmed by analysis of the cerebellum in Zac1 null mice: specific defects were identified in both the medial nuclei and Golgi cells of the posterior vermis.

\section{Additional material}

Additional file 1: Figure S1. Expression of Tbr1 and GAD1 in medial cerebellar nuclei in Zac1 mutants. (A,B) Expression of Tbr1 in E18.5 wild-type (A) and $\mathrm{ZaCl}^{+\mathrm{m} /-}$ (B) deep cerebellar nuclei. (C,D) Expression of GAD1 in E18.5 wild-type (C) and $\mathrm{ZaCl}^{+\mathrm{m} /-}$ (D) deep cerebellar nuclei. Med, Medial cerebellar nuclei.

\section{Abbreviations}

BrdU: 5-bromo-2-deoxyuridine; DCN: deep cerebellar nuclei; E: embryonic day; EGL: external granular layer; GABA: gamma-aminobutyric acid; HBSS: Hank's balanced salt solution; KLC: kinesin light chain; mGluR: metabotropic glutamate receptor; NG: neurogranin; P: postnatal day; PBS: phosphate buffered saline; VZ: ventricular zone.

\section{Acknowledgements}

We would like to thank Laurent Journot for the generous gift of Zac1 antiserum and Zacl null mice. We would also like to thank Nicole Gruenig for animal maintenance. These studies were supported by grants from the Canadian Institutes of Health Research to RH, NIH 5R01NS044262 to KJM, and CIHR MOP - 89994 to CS. We thank Drs Giacomo Consalez and Ferdinando Rossi for their comments on an earlier version of the manuscript.

\section{Author details}

'Department of Cell Biology and Anatomy, Hotchkiss Brain Institute, and Genes and Development Research Group, Faculty of Medicine, University of Calgary, Calgary, Alberta T2N 4N1, Canada. ${ }^{2}$ Department of Human Genetics, University of Chicago, Chicago, Illinois 60637, USA. ${ }^{3}$ Hotchkiss Brain Institute, and Genes and Development Research Group, Faculty of Medicine, University of Calgary, Calgary, Alberta T2N 4N1, Canada.

\section{Authors' contributions}

SC designed and carried out most of the experiments and drafted the initial manuscript. HM conducted the primary culture experiments. KA and KM generated and provided the Math1 null mice. CS provided the Zac1 antibody and Zacl null mice and helped to revise the manuscript. RD carried out the E18.5 Zacl mutant analyses. RH supervised the whole study, was responsible for its coordination, and edited the manuscript. All authors read and approved the final manuscript.

\section{Competing interests}

The authors declare that they have no competing interests.

Received: 18 January 2011 Accepted: 18 May 2011

Published: 18 May 2011

\section{References}

1. Apps R, Hawkes R: Cerebellar cortical organization: a one-map hypothesis. Nat Rev Neurosci 2009, 10:670-681.

2. Chung $\mathrm{SH}$, Marzban $\mathrm{H}$, Hawkes R: Compartmentation of the cerebellar nuclei of the mouse. Neuroscience 2009, 161:123-138.

3. Wingate R: Math-Map(ic)s. Neuron 2005, 48:1-4.

4. Fode C, Ma Q, Casarosa S, Ang SL, Anderson DJ, Guillemot F: A role for neural determination genes in specifying the dorsoventral identity of telencephalic neurons. Genes Dev 2000, 14:67-80.

5. Schuurmans C, Armant O, Nieto M, Stenman JM, Britz O, Klenin N, Brown C, Langevin LM, Seibt J, Tang H, Cunningham JM, Dyck R, Walsh C,

Campbell K, Polleux F, Guillemot F: Sequential phases of cortical specification involve Neurogenin-dependent and -independent pathways. EMBO J 2004, 23:2892-2902.

6. Abdollahi A, Godwin AK, Miller PD, Getts LA, Schultz DC, Taguchi T, Testa JR, Hamilton TC: Identification of a gene containing zinc-finger motifs based on lost expression in malignantly transformed rat ovarian surface epithelial cells. Cancer Res 1997, 57:2029-2034.

7. Spengler D, Villalba M, Hoffmann A, Pantaloni C, Houssami S, Bockaert J, Journot $\mathrm{L}$ : Regulation of apoptosis and cell cycle arrest by Zac1, a novel 
zinc finger protein expressed in the pituitary gland and the brain. EMBO J 1997, 16:2814-2825.

8. Huang SM, Stallcup MR: Mouse Zac1, a transcriptional coactivator and repressor for nuclear receptors. Mol Cell Biol 2000, 20:1855-1867.

9. Huang SM, Schönthal AH, Stallcup MR: Enhancement of p53-dependent gene activation by the transcriptional coactivator Zac1. Oncogene 2001, 20:2134-2143.

10. Hoffmann A, Ciani E, Boeckardt J, Holsboer F, Journot L, Spengler D: Transcriptional activities of the zinc finger protein Zac are differentially controlled by DNA binding. Mol Cell Biol 2003, 23:988-1003.

11. Piras G, El Kharroubi A, Kozlov S, Escalante-Alcalde D, Hernandez L, Copeland NG, Gilbert DJ, Jenkins NA, Stewart CL: Zac1 (Lot1), a potential tumor suppressor gene, and the gene for epsilon-sarcoglycan are maternally imprinted genes: identification by a subtractive screen of novel uniparental fibroblast lines. Mol Cell Biol 2000, 20:3308-3315.

12. Smith RJ, Arnaud P, Konfortova G, Dean WL, Beechey CV, Kelsey G: The mouse Zac1 locus: basis for imprinting and comparison with human ZAC. Gene 2002, 292:101-112.

13. Gardner RJ, Mackay DJG, Mungall AJ, Polychronakos C, Siebert R, Shield JPH, Temple K, Robinson DO: An imprinted locus associated with transient neonatal diabetes mellitus. Hum Mol Genet 2000, 9:589-596.

14. Kamiya M, Judson H, Okazaki Y, Kusakabe M, Muramatsu M, Takada S, Takagi N, Arima T, Wake N, Kamimura K, Satomura K, Hermann R, Bonthron DT, Hayashizaki Y: The cell cycle control gene ZAC/PLAGL1 is imprinted - a strong candidate gene for transient neonatal diabetes. Hum Mol Genet 2000, 9:453-460.

15. Varrault A, Gueydan C, Delalbre A, Bellmann A, Houssami S, Aknin C, Severac D, Chotard L, Kahli M, Le Digarcher A, Pavlidis P, Journot L: Zac1 regulates an imprinted gene network critically involved in the control of embryonic growth. Dev Cell 2006, 11:711-722.

16. Abdollahi A, Roberts D, Godwin A, Schultz D, Sonoda G, Testa J, Hamilton TC: Identification of a zinc-finger gene at 6q25: A chromosomal region implicated in development of many solid tumors. Oncogene 1997, 14:1973-1979.

17. Pagotto U, Arzberger T, Theodoropoulou M, Grubler Y, Pantaloni C, Daeger W, Losa M, Journot L, Stalla GK, Spengler D: The expression of the antiproliferative gene ZAC is lost or highly reduced in non-functioning pituitary adenomas. Cancer Res 2000, 60:6794-6799.

18. Bilanges B, Varrault A, Mazumdar A, Pantaloni C, Hoffmann A, Bockaert J, Spengler $D$, Journot $L$ : Alternative splicing of the imprinted candidate tumor suppressor gene ZAC regulates its antiproliferative and DNA binding activities. Oncogene 2001, 20:1246-1253.

19. Abdollahi A, Pisarcik D, Roberts D, Weinstein J, Cairns P, Hamilton TC: LOT1 (PLAGL1/ZAC1), the candidate tumor suppressor gene at chromosome 6q24-25, is epigenetically regulated in cancer. J Biol Chem 2003, 278:6041-6049.

20. Koy S, Hauses M, Appelt H, Friedrich K, Schackert HK, Eckelt U: Loss of expression of ZAC/LOT1 in squamous cell carcinomas of head and neck. Head Neck 2004, 26:338-344.

21. Valente T, Auladell C: Expression pattern of Zac1 mouse gene, a new zinc-finger protein that regulates apoptosis and cellular cycle arrest, in both adult brain and along development. Mech Dev 2001, 108:207-211.

22. Alam S, Zinyk D, Ma L, Schuurmans : Members of the Plag gene family are expressed in complementary and overlapping regions in the developing murine nervous system. Dev Dyn 2005, 234:772-782.

23. Ma L, Cantrup R, Varrault A, Colak D, Klenin N, Gotz M, McFarlane S, Journot L, Schuurmans C: Zac1 functions through TGFbetall to negatively regulate cell number in the developing retina. Neural Dev 2007, 2:11.

24. Ma L, Hocking JC, Hehr CL, Schuurmans C, McFarlane S: Zac1 promotes a Müller glial cell fate and interferes with retinal ganglion cell differentiation in Xenopus retina. Dev Dyn 2007, 236:192-202.

25. Hiura H, Obata Y, Komiyama J, Shirai M, Kono T: Oocyte growthdependent progression of maternal imprinting in mice. Genes Cells 2006, 11:353-361.

26. Ben-Arie N, Hassan BA, Bermingham NA, Malicki DM, Armstrong D, Matzuk M, Bellen HJ, Zoghbi HY: Functional conservation of atonal and Math1 in the CNS and PNS. Development 2000, 127:1039-1048.

27. Marzban H, Khanzada U, Shabir S, Hawkes R, Langnaese K, Smalla KH, Bockers TM, Gundelfinger ED, Gordon-Weeks PR, Beesley PW: Expression of the immunoglobulin superfamily neuroplastin adhesion molecules in adult and developing mouse cerebellum and their localization to parasagittal stripes. J Comp Neurol 2003, 462:286-301.

28. Marzban H, Sillitoe RV, Hoy M, Chung SH, Rafuse VF, Hawkes R: Abnormal HNK-1 expression in the cerebellum of an N-CAM null mouse. J Neurocytol 2004, 33:117-130.

29. Larouche $M, C h e P$, Hawkes R: Neurogranin expression identifies a novel array of Purkinje cell parasagittal stripes during mouse cerebellar development. J Comp Neurol 2006, 494:215-227.

30. Bulfone A, Sigma SM, Shimamura K, Peterson A, Puelles L, Rubenstein JL: Tbrain-1: a homolog of Brachyury whose expression defines molecularly distinct domains within the cerebral cortex. Neuron 1995, 15:63-78.

31. Brochu G, Maler L, Hawkes R: Zebrin II: a polypeptide antigen expressed selectively by Purkinje cells reveals compartments in rat and fish cerebellum. J Comp Neurol 1990, 291:538-552.

32. Tanaka J, Nakagawa S, Kushiya E, Yamasaki M, Fukaya M, Iwanaga T, Simon Ml, Sakimura K, Kano M, Watanabe M: Gq protein a subunits Gaq and Ga11 are localized at postsynaptic extra-junctional membrane of cerebellar Purkinje cells and hippocampal pyramidal cells. Eur J Neurosci 2000, 12:781-792.

33. Chung $S$, Zhang $Y$, van der Hoorn F, Hawkes R: The anatomy of the cerebellar nuclei in the normal and scrambler mouse as revealed by the expression of the microtubule-associated protein kinesin light chain 3 . Brain Res 2007, 1140:120-131.

34. Furuya S, Makino A, Hirabayashi Y: An improved method for culturing cerebellar Purkinje cells with differentiated dendrites under a mixed monolayer setting. Brain Res Prot 1998, 3:192-198.

35. Tabata T, Sawada S, Araki K, Bono Y, Furuya S, Kano M: A reliable method for culture of dissociated mouse cerebellar cells enriched for Purkinje neurons. J Neurosci Meth 2000, 104:45-53.

36. Fink AJ, Englund C, Daza RA, Pham D, Lau C, Nivison M, Kowalczyk T, Hevner RF: Development of the deep cerebellar nuclei: transcription factors and cell migration from the rhombic lip. J Neurosci 2006, 15:3066-3076.

37. Leto K, Bartolini A, Rossi F: Development of cerebellar GABAergic interneurons: origin and shaping of the "minibrain" local connections. Cerebellum 2008, 7:523-529.

38. Baimbridge KG, Miller JJ: Immunohistochemical localization of calciumbinding protein in the cerebellum, hippocampal formation and olfactory bulb of the rat. Brain Res 1982, 245:223-229.

39. Armstrong CL, Krueger-Naug AMR, Currie RW, Hawkes R: Expression of heat-shock protein Hsp25 in mouse Purkinje cells during development reveals novel features of cerebellar compartmentation. J Comp Neurol 2001, 429:7-21.

40. Larouche M, Hawkes R: From clusters to stripes: the developmental origins of adult cerebellar compartmentation. Cerebellum 2006, 5:77-88.

41. Nunzi MG, Shigemoto R, Mugnaini E: Differential expression of calretinin and metabotropic glutamate receptor mGluR1 alpha defines subsets of unipolar brush cells in mouse cerebellum. J Comp Neurol 2002, 451:189-199.

42. Sekerkova G, lijic E, Mugnaini E: Time of origin of unipolar brush cells in the rat cerebellum as observed by prenatal bromodeoxyuridine labeling. Neuroscience 2004, 127:845-858.

43. Chung SH, Marzban H, Watanabe M, Hawkes R: Phospholipase C $\beta 4$ expression reveals a novel subset of unipolar brush cells in the adult mouse cerebellum. Cerebellum 2009, 8:267-276.

44. Bastianelli E: Distribution of calcium-binding proteins in the cerebellum. Cerebellum 2003, 2:242-262.

45. Singec I, Knoth R, Ditter M, Frotscher M, Volk B: Neurogranin expression by cerebellar neurons in rodents and non-human primates. J Comp Neurol 2003, 459:278-289.

46. Simat M, Parpan F, Fritschy JM: Heterogeneity of glycinergic and gabaergic interneurons in the granule cell layer of mouse cerebellum. J Comp Neurol 2007, 500:71-83.

47. Popoff S: Weiterer Beitrag zur Frage über die Histogenese der Kleinhirnrinde. Biologischer Centrlblatt 1896, 16:462-466.

48. Athias M: Recherches sur l'histogenese de l'ecorce du cervelet. Journal de I'Anatomie et de la Physiologie Normale 1897, 33:372-404.

49. Hausmann B, Mangold U, Sievers J, Berry M: Derivation of cerebellar Golgi neurons from the external granular layer: evidence from explantation of external granule cells in vivo. J Comp Neurol 1985, 22:511-522. 
50. Ramon y Cajal S: Histologie du Système Nerveux de l'Homme et des Vertébrés Madrid: Instituto Ramon y Cajal; 1911.

51. Altman J, Bayer SA: Time of origin and distribution of a new cell type in the rat cerebellar cortex. Exp Brain Res 1977, 29:265-274

52. Zhang L, Goldman JE: Generation of cerebellar interneurons from dividing progenitors in white matter. Neuron 1996, 16:47-54.

53. Sidman RL, Miale IL, Feder N: Cell proliferation study and migration in the primitive ependymal zone: An autoradiographic study of histogenesis in the nervous system. Exp Neurol 1959, 1:322-333.

54. Miale IL, Sidman RL: An autoradiographic analysis of histogenesis in the mouse cerebellum. Exp Neurol 1961, 4:277-297.

55. Aoki E, Semba R, Kashiwamata S: New candidates for GABAergic neurons in the rat cerebellum: an immunocytochemical study with anti-GABA antibody. Neurosci Lett 1986, 68:267-271.

56. Zhang L, Goldman E: Developmental fates and migratory pathways of dividing progenitors in the postnatal rat cerebellum. J Comp Neurol 1996, 370:536-550

57. Machold R, Fishell G: Math1 is expressed in temporally discrete pools of cerebellar rhombic-lip neural progenitors. Neuron 2005, 48:17-24.

58. Wang WY, Rose MF, Zoghbi HY: Math1 expression redefines the rhombic lip derivatives and reveals novel lineages within the brainstem and cerebellum. Neuron 2005, 48:31-43.

59. Jensen P, Zoghbi HY, Goldowitz D: Dissection of the cellular and molecular events that position cerebellar Purkinje cells: a study of the math1 null-mutant mouse. J Neuroscience 2002, 22:8110-8116.

60. Sillitoe RV, Hawkes R: Whole-mount immunohistochemistry: a highthroughput screen for patterning defects in the mouse cerebellum. $J$ Histochem Cytochem 2002, 50:235-244.

61. Chen S, Hillman DE: Colocalization of neurotransmitters in the deep cerebellar nuclei. J Neurocytol 1993, 22:81-91.

62. De Zeeuw Cl, Berrebi AS: Postsynaptic targets of Purkinje cell terminals in the cerebellar and vestibular nuclei of the rat. Eur J Neurosci 1995, 7:2322-2333

63. Teune TM, van der Burg J, De Zeeuw Cl, Voogd J, Ruigrok TJ: Single Purkinje cell can innervate multiple classes of projection neurons in the cerebellar nuclei of the rat: a light microscopic and ultrastructural tripletracer study in the rat. J Comp Neurol 1998, 392:164-178.

64. Altman J, Bayer SA: Embryonic development of the rat cerebellum. I. Delineation of the cerebellar primordium and early cell movements. J Comp Neurol 1985, 231:1-26.

65. Altman J, Bayer SA: Embryonic development of the rat cerebellum. II. Translocation and regional distribution of the deep neurons. J Comp Neurol 1985, 231:27-41.

66. Goldowitz D, Hamre K: The cells and molecules that make a cerebellum Trends Neurosci 1998, 21:375-382.

67. Maricich SM, Herrup K: Pax-2 expression defines a subset of GABAergic interneurons and their precursors in the developing murine cerebellum. J Neurobiol 1999, 41:281-294.

68. Hoshino M, Nakamura S, Mori K, Kawauchi T, Terao M, Nishimura Y Fukuda A, Fuse T, Matsuo N, Sone M, Watanabe M, Bito H, Terashima T, Wright CV, Kawaguchi Y, Nakao K, Nabeshima Y: Ptf1a, a bHLH transcriptional gene, defines GABAergic neuronal fates in cerebellum. Neuron 2005, 47:201-213

69. Golgi C: Sulla fina anatomia degli organi centrali del sistema nervoso IV. Sulla fina anatomia delle circonvoluzioni cerebellari. Rivista Sperimentale di Freniatria 1883, 9:1-17.

70. Palay SL, Chan-Palay V: Cerebellar Cortex: Cytology and Organization Berlin, Heidelberg, New York: Springer-Verlag; 1974

71. De Schutter E, Bjaalie JG: Coding in the granular layer of the cerebellum. Prog Brain Res 2001, 130:279-296.

72. Chizhikov W, Lindgren AG, Mishima Y, Roberts RW, Aldinger KA Miesegaes GR, Currle DS, Monuki ES, Millen KJ: Lmx1a regulates fates and location of cells originating from the cerebellar rhombic lip and telencephalic cortical hem. Proc Natl Acad Sci USA 2010, 107:10725-10730.

73. Geurts FJ, De Schutter E, Dieudonné S: Unraveling the cerebellar cortex: cytology and cellular physiology of large-sized interneurons in the granular layer. Cerebellum 2003, 2:290-229.

74. Geurts FJ, Timmermans J, Shigemoto R, De Schutter E: Morphological and neurochemical differentiation of large granular layer interneurons in the adult rat cerebellum. Neuroscience 2001, 104:499-512.
75. Valente T, Auladell C: Zac1 is expressed in progenitor/stem cells of the neuroectoderm and mesoderm during embryogenesis: Differential phenotype of the Zac1-expressing cells during development. Dev Dyn 2005, 233:667-679.

76. Obata K, Ito M, Ochi R, Sato N: Pharmacological properties of the postsynaptic inhibition by Purkinje cell axons and the action of gammaaminobutyric acid on Deiters' neurons. Exp Brain Res 1967, 4:43-57.

77. Grimaldi P, Parras C, Guillemot F, Rossi F, Wassef M: Origins and control of the differentiation of inhibitory interneurons and glia in the cerebellum. Dev Biol 2009, 328:422-433.

78. Bilanges B, Varrault A, Basyuk E, Rodriguez C, Mazumdar A, Pantaloni C, Bockaert J, Theillet C, Spengler D, Journot L: Loss of expression of the candidate tumor suppressor gene ZAC in breast cancer cell lines and primary tumors. Oncogene 1999, 18:3979-3988.

79. Kamikihara T, Arima T, Kato K, Matsuda T, Kato H, Douchi T, Nagata Y, Nakao M, Wake N: Epigenetic silencing of the imprinted gene ZAC by DNA methylation is an early event in the progression of human ovarian cancer. Int J Cancer 2005, 115:690-700.

80. Hensen K, Braem C, Declercq J, Van Dyck F, Dewerchin M, Fiette L, Denef C, Van de Ven WJ: Targeted disruption of the murine Plag1 proto-oncogene causes growth retardation and reduced fertility. Dev Growth Differ 2004, 46:459-470.

doi:10.1186/1749-8104-6-25

Cite this article as: Chung et al:: Zac1 plays a key role in the development of specific neuronal subsets in the mouse cerebellum. Neural Development 2011 6:25

\section{Submit your next manuscript to BioMed Central and take full advantage of:}

- Convenient online submission

- Thorough peer review

- No space constraints or color figure charges

- Immediate publication on acceptance

- Inclusion in PubMed, CAS, Scopus and Google Scholar

- Research which is freely available for redistribution

Submit your manuscript at www.biomedcentral.com/submit
C) Biomed Central 